\title{
Hedgehog-independent overexpression of transforming growth factor- $\beta 1$ in rhabdomyosarcoma of Patched1 mutant mice
}

\author{
MELANIE EICHENMÜLLER ${ }^{1}$, REGINE BAUER $^{2}$, DIETRICH VON SCHWEINITZ ${ }^{1}$, \\ HEIDI HAHN $^{2}$ and ROLAND KAPPLER ${ }^{1,2}$ \\ ${ }^{1}$ Pediatric Surgical Clinic, Dr. von Hauner Children's Hospital, Ludwig-Maximilians-University Munich, D-80337 Munich; \\ ${ }^{2}$ Institute of Human Genetics, University of Goettingen, D-37073 Goettingen, Germany
}

Received March 16, 2007; Accepted May 11, 2007

\begin{abstract}
The tumor suppressor gene PATCHED1 (PTCH1) is a member of the hedgehog signaling pathway and causatively associated with several human sporadic and familial cancers, including those of the skin, muscle and brain. Inactivation of one Ptchl allele in the mouse results in the development of medulloblastoma and rhabdomyosarcoma (RMS), the latter being a malignant tumor of skeletal muscle origin. To identify genes involved in the pathogenesis of Ptchl-associated RMS, we have monitored the expression of 588 genes in RMS and normal skeletal muscle (SM) of heterozygous $P t c h 1^{\text {neo67/+ }}$ mice using cDNA array technology. RMS displayed increased transcript levels of several genes such as transforming growth factor- $\beta 1$ (Tgfb1), insulin-like growth factor 2 (Igf2), villin 2 (Vil2), integrin $\beta 1$ (Itgb1), Sloan-Kettering viral oncogene homolog (Ski), and insulinlike growth factor binding protein 3 (Igfbp 3$)$, as well as numerous genes coding for structural components of myogenic cells such as myosin light polypeptide 4 (Myl4), myosin light polypeptide 6 (Myl6), and vimentin (Vim). Detailed promoter analysis revealed a putative Gli binding site in the second promoter region (P2) of the murine $T g f b 1$ gene. However, using reporter assay we show that the P2 promoter is not responsive to hedgehog signaling. We furthermore describe that $T g f b l$ expression could not be activated in $\mathrm{C} 2 \mathrm{C} 12$ myoblasts in the presence of murine Shh-N peptide and that Tgfbl is equally expressed in both wild-type and Ptchl-deficient mouse embryos. In line with this, TGFB1 was strongly expressed in human RMS cell lines independently of the GLII expression status. In summary, our results suggest that aberrant expression of $T g f b 1$ may be involved in RMS development in a way that is independent of hedgehog signaling.
\end{abstract}

Correspondence to: Dr Roland Kappler, Pediatric Surgical Clinic, Dr. von Hauner Children's Hospital, Ludwig-MaximiliansUniversity Munich, Lindwurmstr. 4, D-80337 Munich, Germany E-mail: roland.kappler@med.uni-muenchen.de

Key words: Patched1, rhabdomyosarcoma, Tgfb1, arrays, mouse

\section{Introduction}

RMS is the most common soft-tissue sarcoma in children, representing approximately $9 \%$ of pediatric solid cancers (1). This tumor is thought to arise as a consequence of regulatory disruption of skeletal muscle progenitor cell growth and differentiation, yet the precise cell of origin is not entirely clear (2). The two major histopathological classifications of RMS, the embryonal form (ERMS) and the rarer alveolar form (ARMS), are described to distinguish the two types not only regarding their histology and their degree of differentiation, but also their prognosis (3). A recent study has reported estimated 3-year failure-free survival rates of 66 and $83 \%$ for ARMS and ERMS, respectively (4). It has furthermore been demonstrated that both subtypes are distinguishable based on the detection of distinct genetic markers (5). ERMS is generally characterized by the loss of heterozygosity at the chromosomal band 11p15 (6), a region which harbors the imprinted genes $I G F 2$ and H19. In contrast, the majority of ARMS are reported to have the characteristic reciprocal translocations $\mathrm{t}(2 ; 13)(\mathrm{p} 35 ; \mathrm{q} 14)$ and $\mathrm{t}(1 ; 13)(\mathrm{p} 36 ; \mathrm{q} 14)$, giving rise to PAX3- and PAX7-FKHR fusion proteins, respectively $(7,8)$. Common to all tumors is their positive immunochemical staining for certain skeletal muscle structural proteins, such as alpha actin, fast myosin, myosin heavy chain as well as certain proteins not specific for muscle as desmin and vimentin $(9,10)$.

Coupled with the relative rarity of this tumor, various mouse model systems for RMS have been developed which allow for the investigation of the molecular mechanisms underlying tumorigenesis of RMS and the delineation of novel targets that may be important in developing new therapeutic strategies for the treatment of RMS. One important RMS mouse model was introduced by Hahn and colleagues in 1998 (11), in which mice bearing only one functional Ptchl allele develop neoplasms resembling human embryonal RMS on both histological and molecular levels (12-14). The human homologue of the Drosophila segment polarity gene PTCH1 encodes an inhibitory component of the receptor complex of the hedgehog signaling pathway, which is implicated in a variety of human cancers $(15,16)$. Mutations of $P T C H 1$ were first described in patients of the nevoid basal cell carcinoma syndrome or Gorlin syndrome $(17,18)$. These patients are predisposed to a range of neoplasias including 
basal cell carcinoma, medulloblastoma, and RMS (19). Even though subsequent studies have shown PTCH1 mutations in sporadic forms of basal cell carcinoma and medulloblastoma (15), PTCH1 mutations in sporadic RMS are relatively rare (20). However, overexpression of the hedgehog target genes PTCHI and GLII at the mRNA level has recently been reported in nearly all cases of sporadic rhabdomyoma and RMS, indicating an active hedgehog signaling pathway (21).

The cDNA microarray technology (22) provides a unique opportunity to simultaneously monitor the expression of thousands of genes and has been successfully applied to almost all of the main human cancers including leukemia (23), lymphoma (24), adenocarcinoma of the lung (25), breast (26) and prostate (27). To provide new insights into molecular mechanisms by which RMS arise, we have monitored the gene expression of 588 genes in RMS of heterozygous Ptchl $1^{\text {neo67/+ }}$ mice using the cDNA array technology. Our gene expression profiling approach has led to the identification of $T g f b l$ as a highly expressed gene in RMS of the Ptchl mouse model. Moreover, our observations suggest that aberrant expression of the $T g f b l$ gene may be involved in the development of RMS independently of hedgehog signaling.

\section{Materials and methods}

Tissue specimens. Rhabdomyosarcoma (RMS) and normal skeletal muscle (SM) as a reference were excised from heterozygous $P t c h 1^{\text {neo67/+ }}$ mice maintained on a CD1 background (11), immediately frozen in liquid nitrogen and stored at $-80^{\circ} \mathrm{C}$. Tumors were collected with consideration of all necessary legal requirements. Histological analysis of $5 \mu \mathrm{m}$ hematoxylin/eosin stained tumor sections was carried out by a pathologist. Only RMS tissues containing $>90 \%$ tumor cells were used in this study. E9.5 Ptch $1^{+/+}$and Ptch $1^{\text {neo67/neo67 }}$ embryos from cross-bred Ptch $1^{\text {neo67/+ }}$ mice were isolated and genotyped as previously described (11).

Tumor cell lines. RMS cell lines (RH-1, RH-30, RMS-13, and $\mathrm{RD})$ and the A673 Ewing sarcoma cell line were purchased from the German Collection of Microorganisms and Cell Cultures (DSMZ, Braunschweig, Germany) and American Type Culture Collection (ATCC, Manassas, VA). Cells were maintained as the suppliers recommended.

RNA extraction. E9.5 embryos of the same Ptchl genotype were pooled and total RNA was prepared in TRIzol (Invitrogen, Carlsbad, CA) according to the manufacturer's instructions. In the same way total RNA was extracted from tumor and reference tissue as well as tumor cell lines. For cDNA array experiments, total RNA was treated with DNase (Roche Diagnostics, Mannheim, Germany) and poly(A) RNA was prepared using the mRNA Oligotex Kit (Qiagen, Hilden, Germany).

cDNA array hybridization. We used an ATLAS mouse cDNA expression array containing 588 gene specific cDNAs spotted in duplicate on a nylon membrane, which also includes cDNAs corresponding to housekeeping genes and negative controls (Clontech, Palo Alto, CA). Poly(A) RNA of RMS and $\mathrm{SM}$ tissue $(1 \mu \mathrm{g})$ was converted into labeled cDNA
Table I. Gene-specific primers used for RT-PCR.

\begin{tabular}{ll}
\hline Primer & \multicolumn{1}{c}{ Sequence (5'-3' orientation) } \\
\hline Vim-F & TTCAAGAACACCCGCACCAACGAGA \\
Vim-R & AGCCTCAGAGAGGTCAGCAAACTT \\
Myl4-F & GAGAGATGAAGATCACCTACGG \\
Myl4-R & TTGATGCAGCCATTGGCATCCT \\
Mmp14-F & ATGTCTCCCGCCCCTCGACC \\
Mmp14-R & TCAGACCTTGTCCAGCAGCGAAC \\
Myl6-F & TTCCAGCTGTTTGACCGAACAGGT \\
Myl6-R & AACCATTGCTGTCCTCATGCCCT \\
Inha-F & ATGGTGAGCCAGCGGTCTCTGCT \\
Inha-R & CGGAGGTGCTTTTAGATACAAGCACAGTG \\
Ptma-F & TGACGATGTGGACACCAAGA \\
Ptma-R & AAACGCTCTGAAGGCTGGTT \\
Itgb1-F & ATGAATTTGCAACTGGTTTCCTGGA \\
Itgb1-R & CTTGGTGTTGCAAAATCCGCCT \\
Gpx3-F & ATGGCGGTATGAGTGGTACCATCT \\
Gpx3-R & GATGTCCATCTTGACGTTGCTGAC \\
Ccng-F & ACTGGAAGGCATTCACTGTG \\
Ccng-R & AAGACACTCTGGCAGTTTCC \\
\hline Gli1-F & GGCTTTCATCAACTCTCGCTGTAC \\
Gli1-R & AGCTTGCACACGTATGGCTTCTC \\
Tgfb1-F & ACGCCTGAGTGGCTGTCTTTGA \\
Tgfb1-R & GCGCACAATCATGTTGGACAACT \\
Gapdh-F & ATCTTCTTGTGCAGTGCCAG \\
Gapdh-R & ATGGCATGGACTGTGGTCAT \\
\hline
\end{tabular}

F, forward primer; R, reverse primer.

probe by using gene specific primers and ${ }^{32} \mathrm{P}-\mathrm{dATP}$ according to the recommendation of the manufacturer (Clontech). Unincorporated nucleotides were removed from labeled cDNA with MicroSpin G-50 columns (Pharmacia, Freiburg, Germany). Hybridization and stringency washes were carried out according to the manufacturer's instructions (Clontech). Hybridized membranes were exposed for $24 \mathrm{~h}$ to imaging plates BAS-III S (Fuji Photo Film, Tokyo, Japan) and digital images were captured using a FUJIX BAS1000 phosphor imager (Fuji Photo Film). Data acquisition by densitometric scanning was then performed with the PCBAS $2.09 \mathrm{~g}$ software (Raytest, Straubenhardt, Germany). Signal intensities were corrected for local background and normalized to the housekeeping gene Gapdh. Expression of this gene emerged similar in RMS and SM tissues of Ptch $1^{\text {neo67/+ }}$ mice, as previously described (14). Data analysis was performed including only genes whose expression was altered in both experiments at least 2-fold between RMS and the corresponding SM tissue.

Northern hybridization. For Northern blot hybridization, $10 \mu \mathrm{g}$ of total RNA were size fractioned, transferred to a nylon membrane and hybridized according to standard protocols (28). Probe labeling was performed using the Prime-It RmT kit (Stratagene, La Jolla, CA). Probes for the mouse 
Igfbp3 and $T g f b 1$ genes were released from IMAGE clones AA990365 and AA821506, respectively (RZPD, Berlin, Germany). The Igf2 probe was described previously (11). The remaining murine DNA probes were generated from total RNA isolated from mouse embryo by RT-PCR using primers as given in Table I. Probes for the human GLI1, TGFB1 and GAPDH genes were generated by insert release from IMAGE clones AI473373, AI304490 and BF338366, respectively (RZPD). All probes used were sequence verified prior to hybridization using an ABI PRISM BigDye Terminator Cycle Sequencing Ready Reaction Kit (Applied Biosystems, Foster City, CA) and an ABI PRISM 377 DNA Sequencer (Applied Biosystems).

Sonic hedgehog stimulation. C2C12 myoblasts were obtained from ATCC and maintained as the supplier recommended. For sonic hedgehog (Shh) stimulation experiments, cells were grown in DMEM containing 10\% FCS in 6-well plates to $90 \%$ confluency and then changed to low serum medium (DMEM with $0.5 \%$ FCS) containing $1 \mu \mathrm{g} / \mathrm{ml}$ recombinant mouse Shh amino-terminal peptide (Shh-N; R\&D Systems, Minneapolis, MN) or Shh-N vehicle ( $0.1 \%$ BSA/PBS). For the inhibition of hedgehog signaling, cells were additionally exposed to 3-keto-N-aminoethyl aminocaproyl dihydrocinnamoyl cyclopamine (Toronto Research Chemicals, Toronto, Canada) in a final concentration of $1 \mu \mathrm{M}$. Total RNA was isolated after indicated times using TRIzol (Invitrogen) as described by the supplier.

Semi-quantitative reverse transcription-PCR. Reverse transcription of total RNA was performed using random hexamers (Roche Diagnostics) and SuperScriptII reverse transcriptase (Invitrogen). PCR amplifications of the genes Gli1, Tgfb1, and Gapdh were carried out with $50 \mathrm{ng}$ of cDNA, $200 \mathrm{nM}$ forward primer and reverse primer (Table I) in a $20 \mu 1$ final reaction mixture for 25 (Gapdh) and 28 cycles (Glil and Tgfbl) consisting of $30 \mathrm{sec}$ denaturation at $95^{\circ} \mathrm{C}$, hybridization of primers for $30 \mathrm{sec}$ at $55^{\circ} \mathrm{C}$ and extension for $1 \mathrm{~min}$ at $72^{\circ} \mathrm{C}$. Amplification of Gapdh as an endogenous control was performed to standardize the amount of sample RNA. Digital images of PCR fragments were captured using the PCBAS $2.09 \mathrm{~g}$ software (Raytest).

Reporter assays. The 5'-untranslated leader sequence of the murine $T g f b l$ gene from the first transcription initiation site up to the translational initiation codon (29) was PCR amplified using the IMAGE clone BU511657 (RZPD) as a template and Tgfb 1 forward (5'-CTGCCTCGAGTCGCGCCCAGG CCGTCCCCCTCCTC-3') and reverse (5'-CTGCCCATGG GGGAGGCGGCGCCCCACGGCA-3') primers with XhoI and NcoI overhangs (underlined), respectively. The 849 bp PCR fragment containing the P2 promoter and the putative Gli1 binding site was cloned into the XhoI and NcoI sites of the pGL3 basic firefly luciferase plasmid (Promega, Madison, WI) to produce pGL3-Tgfb1. The pGL3-Tgfb1-Mut reporter plasmid was made by a PCR-directed linker scanning mutagenesis approach with Tgfb1-Mut forward (5'-GCCA $\underline{\mathrm{AA}}$ GCTTAACTTTTGGATCTCAGAGAGCGCTCA-3') and reverse (5'-CTCCAAGCTTCTTAAATAGGGGAGCTAC TGCCA-3') primers with HindIII overhangs (underlined) as
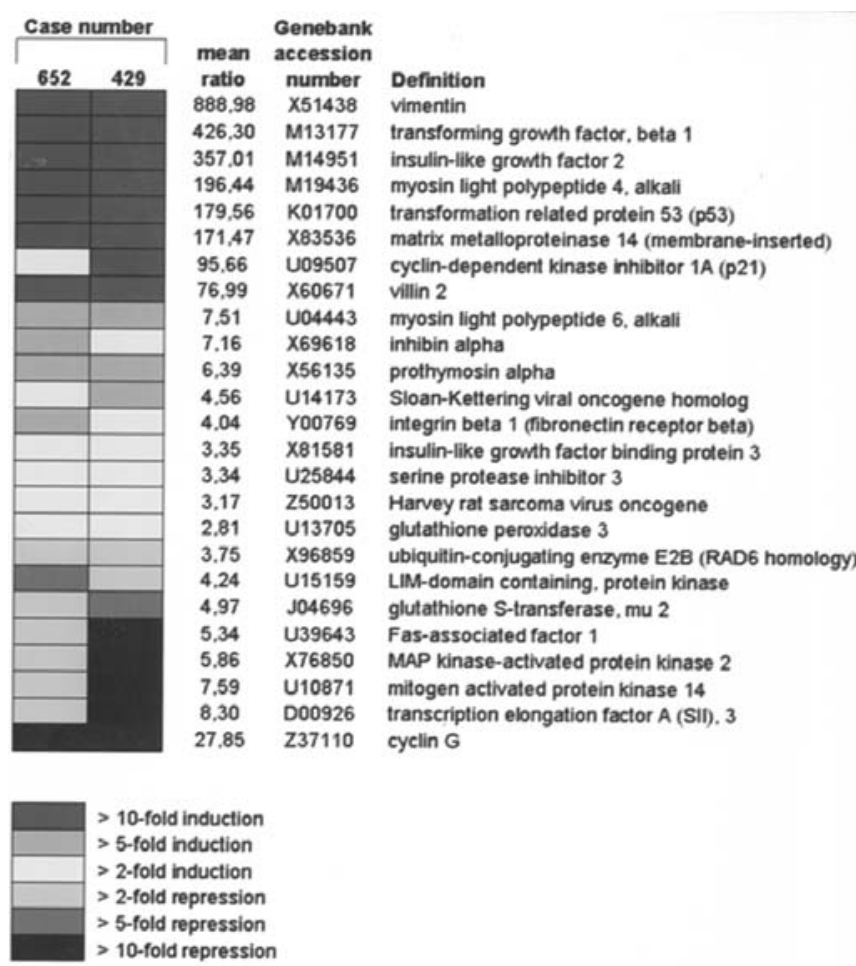

Figure 1. Gene expression profiling in RMS of Ptch $1^{\text {neo67/+ }}$ heterozygous mice. Panel of genes differentially expressed in RMS of Ptch $1^{\text {neo67/+ }}$ heterozygous mice relative to normal skeletal muscle (SM). Genes are listed in order of fold induction and highlighted for each case with very dark grey ( $>10$-fold induction), grey ( $>5$-fold induction), white ( $>2$-fold induction), light grey ( $>2$ fold repression), dark grey ( $>5$ fold repression), or black ( $>10$-fold repression).

described by Gustin and Burk (30). The plasmid p11x Gli1$\mathrm{BS}$, which contains Gli1-binding sites in front of a herpes simplex virus thymidine kinase (HSV-TK) promoter and firefly luciferase was used as a positive control for Shh activation (31). All constructs were sequence verified. The plasmid pGL3 (Promega) was used as a negative control. The reference plasmid pRL-TK, containing the Renilla luciferase gene driven by the HSV-TK promoter, was co-transfected with reporter plasmids for normalization purposes. NIH-3T3 cells (ATCC) were seeded in 6-well plates the day before transfection. Cells were transfected with $1 \mu \mathrm{g}$ reporter plasmid, $1 \mu \mathrm{g}$ effector plasmid, and $10 \mathrm{ng}$ reference plasmid using FuGene 6 transfection reagent (Roche Diagnostics) as indicated. Forty-eight hours after transfection, cells were lysed and reporter gene activity was determined using the Dual-Glo Luciferase Reporter Assay System (Promega). Firefly luciferase activity was normalized to Renilla luciferase activity. All reporter assay experiments were repeated at least three times, and transfections done in duplicate.

\section{Results}

Gene expression profiling revealed $T g f b 1$ as a candidate gene in Ptchl-associated RMS. To identify candidate genes involved in tumorigenesis of Ptchl-associated RMS, we screened for differentially expressed genes in 2 matched cases of RMS and SM tissue of Ptch $1^{\text {neo67/+ }}$ mice using cDNA array technology. RNA was prepared from tumor and control 


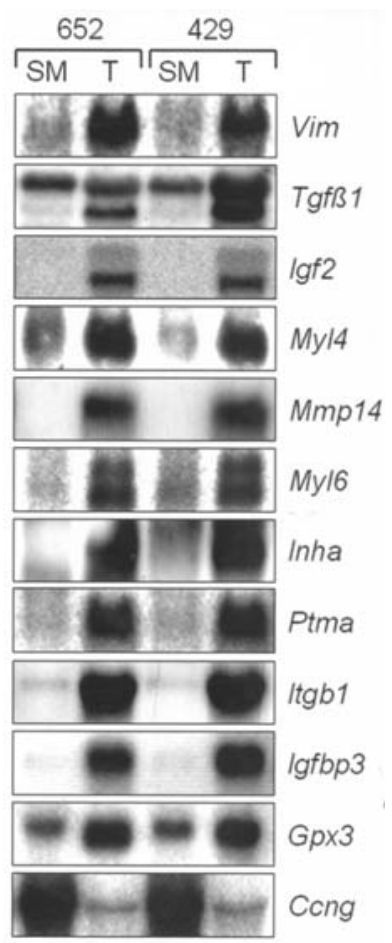

Figure 2. Verification of microarray findings. Selected candidate genes of the cDNA microarray screen were analyzed by means of Northern blot analysis using gene-specific DNA probes in normal skeletal muscle (SM) and rhabdomyosarcoma (T) of two Ptch $1^{\text {neo67// }}$ heterozygous mice.

tissues, ${ }^{32} \mathrm{P}-$ labeled and hybridized to cDNA arrays containing 588 known mouse genes. By comparing the specific hybridization patterns of both samples, we found 25 genes with striking differences in signal intensity (Fig. 1). Genes with increased expression in RMS tissue included known RMS-associated genes (Igf2, Vil2, p21, p53, Itgb1), genes implicated in Tgf- $\beta$ signaling (Tgfbl, Ski, Igfbp 3$)$, as well as numerous genes coding for structural components of myogenic cells such as Myl4, Myl6, and Vim. In contrast, genes like cyclin $G(C c n g)$ and transcription elongation factor S-II as well as genes encoding protein kinases (LIM-domain containing protein kinase, MAP kinase-activated protein kinase 2, mitogen-activated protein kinase 14) displayed reduced transcript levels in RMS tissue.

To verify the detected gene expression alterations we subsequently performed Northern blot analysis using specific DNA probes for the murine genes. Hybridization of the respective ${ }^{32} \mathrm{P}$-labeled DNA probes to total RNA from RMS and SM revealed strong signals for Vim, Tgfbl, Igf2, Myl4, matrix metalloproteinase 14 (Mmp14), Myl6, inhibin a (Inha), prothymosin a (Ptma), Itgb1, Igfbp 3, and glutathione peroxidase $3(G p \times 3)$ in tumor and weak signals in reference tissue, whereas the Ccng probe generated an inverse pattern (Fig. 2). Interestingly, RMS tissue exhibited an additional shorter transcript for $T g f b 1$ compared to SM, which was strongly expressed only in the tumor.

$P 2$ promoter of the murine Tgfbl gene is not responsive to Glil. To determine whether the identified genes upregulated in Ptchl-associated RMS were direct downstream targets of hedgehog signaling, we exploited the fact that murine Gli is
A.)

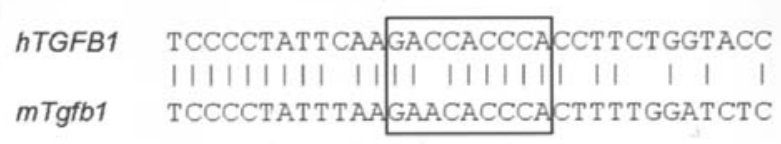

Gli binding site

B.)

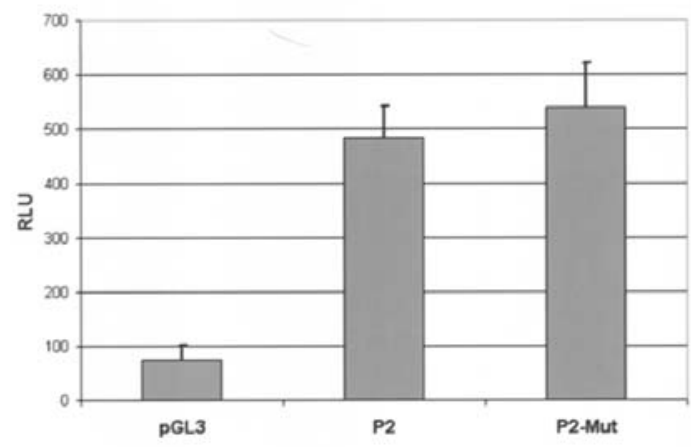

C.)

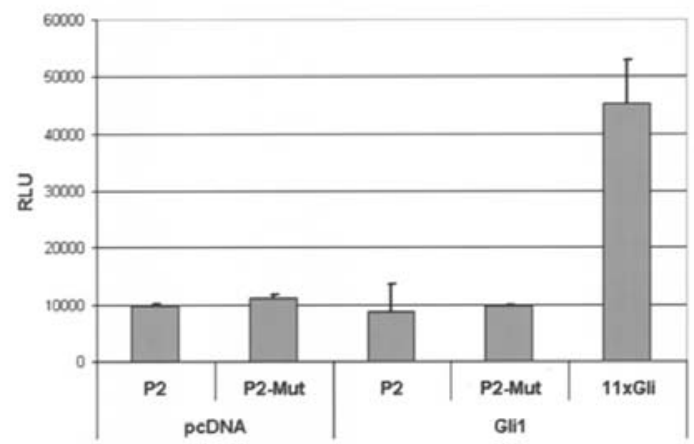

Figure 3. P2 promoter of the murine $T g f b 1$ gene is not responsive to Gli1. (A) Portion of the 5' untranslated region of the human and murine Tgfb1/TGFB1 gene harboring the putative Gli binding sequence (square) at position +250 upstream of the translational start site. (B and C) NIH-3T3 fibroblasts were transiently transfected with the indicated reporter and expression plasmids. Luciferase activity of the reporters was measured $48 \mathrm{~h}$ after transfection and normalized to the amount of Renilla luciferase activity. RLU, relative luminescence units.

a sequence-specific DNA-binding protein that interacts with the motif GAACACCCA (32). Among the genes verified by Northern blot analysis (see above), the $T g f b l$ gene contained a putative Gli binding site with the 9-bp consensus sequence in the $\mathrm{P} 2$ promoter at position +250 upstream of the translational start site (Fig. 3A). Interestingly, the human TGFB1 P2 promoter region contains the consensus sequence GACCAC CCA of the human GLI protein (33).

Since we found a significant increase in the expression of a shorter $T g f b 1$ transcript in the tumor (Fig. 2), we wondered whether this expression could be induced through binding of Gli proteins to the $\mathrm{P} 2$ promoter of the $T g f b 1$ gene. Thus, we cloned the 5'-untranslated region (5'-UTR) of the murine $T g f b 1$ gene in front of the luciferase gene and additionally mutated the Gli binding site from GAACACCCA to GAAG CTTAA. The resulting two reporter plasmids were checked for responsiveness using luciferase assays in NIH-3T3 cells, since these cells were capable of promoting P2-dependent transcription (29). We found that the entire 5'-UTR containing the wild-type Gli binding site (P2) was able to induce luciferase expression 6.5-fold (Fig. 3B) compared to the 
A.)

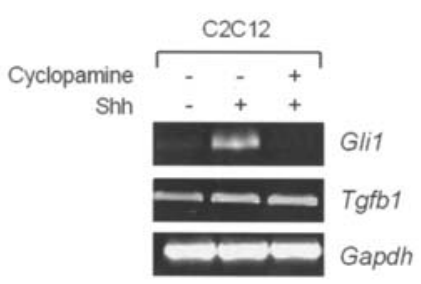

B.)

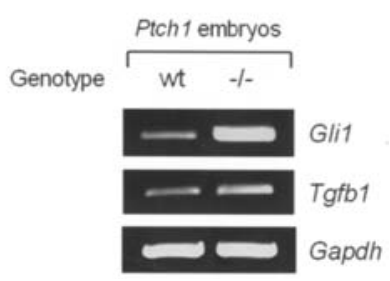

Figure 4. $T g f b 1$ expression is not induced by hedgehog signaling. (A) Expression of Tgfb1, Gli1 and Gapdh was determined in C2C12 myoblasts (lane 1) after exposure to Shh-N peptide $(1 \mu \mathrm{g} / \mathrm{ml})$ either in the absence (lane 2) or presence (lane 3) of the hedgehog inhibitor cyclopamine $(1 \mu \mathrm{M})$ using semi-quantitative RT-PCR. Equal Gapdh amounts indicate comparable amounts of RNA starting material. (B) Semi-quantitative RT-PCR was used to check for Gli1 and Tgfbl expression in E9.5 Ptch1 ${ }^{+++}$(lane 1) and Ptch $1^{\text {neo67/neo67 }}$ (lane 2) embryos. Comparable Gapdh amounts served as an internal standard.

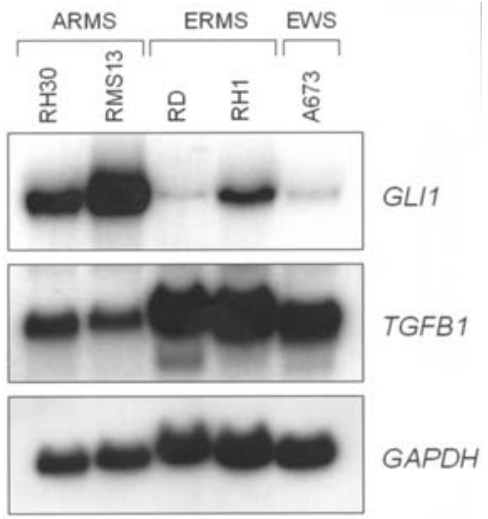

Figure 5. Strong expression of $T G F B 1$ independent of $G L I 1$ in human rhabdomyosarcoma cell lines. GLII and TGFB1 expression was analyzed in two alveolar (ARMS) and two embryonal (ERMS) rhabdomyosarcoma as well as one Ewing sarcoma (EWS) by means of Northern blot analysis using gene-specific DNA probes. GAPDH expression indicates equivalent amounts of RNA.

empty control vector (pGL3). However, the mutated reporter construct (P2-Mut) induced luciferase expression in a similar way (7.2-fold), thus emphasizing that the Gli binding site is not necessary for the activation of the reporter in unstimulated NIH-3T3 cells. We then asked whether activation of hedgehog signaling could enhance the reporter activity and whether there is a difference between the wild-type and the mutated reporter. To question this, we co-transfected the murine Gli1 expression plasmid and the respective reporter plasmid into NIH-3T3 cells (Fig. 3C). We detected no increase in wildtype and mutated reporter activity in Glil transfected cells compared to empty vector controls. To verify that the Glil effector is functional, we performed transfections using the murine Glil expression plasmid together with the $11 \mathrm{xGli}$ reporter, which resulted in a strong activation of luciferase activity. Thus, our data indicate that the Gli binding site found in the $\mathrm{P} 2$ promoter of $T g f b 1$ is not responsive to Gli1 and therefore might not be responsible for the P2-driven expression of the $T g f b l$ transcript.

Cells with activated hedgehog signaling exhibit no increase in Tgfbl expression. Having demonstrated that the Gli binding site in the 5'-UTR of the Tgfbl gene is not responsive to Gli1 in NIH-3T3 cells, we wanted to see whether other cell types with an activated hedgehog pathway exhibit enhanced $T g f b 1$ expression. First, we examined $T g f b l$ transcript levels in myogenic cells stimulated by the ligand Shh by means of semi-quantitative RT-PCR. Glil expression was monitored to indicate activation of the hedgehog signaling pathway. We found that stimulation of murine C2C12 myoblasts with mouse Shh-N results in a strong Glil expression (Fig. 4A). In sharp contrast, $T g f b l$ expression was uniformly strong in unstimulated and stimulated cells. Since it is known that hedgehog signaling could be specifically inhibited by the plant alkaloid cyclopamine (34), we repeated the experiments in the presence of this inhibitory compound. As expected, Gli1 expression was blocked by the addition of cyclopamine, whereas $T g f b l$ expression was unaffected by this treatment. These results demonstrate that $T g f b l$ expression could not be induced by hedgehog signaling in myogenic cells, as described for fibroblasts (see above).

Second, we wanted to ascertain whether $T g f b l$ might be transcriptionally activated by a constitutively activated Shh signaling pathway by analyzing $T g f b l$ expression in Ptchl ${ }^{\text {ne067/neo67 }}$ embryos by means of semi-quantitative RTPCR. The homozygous loss of Ptchl alleles resulted in a strong increase in Glil expression, which was used as a positive control for the induction of the pathway (Fig. 4B). However, Tgfbl expression was not elevated in Ptchldeficient embryos, again indicating that $T g f b l$ is not a target gene of hedgehog signaling.

Human tumor cells show strong expression of TGFBI independent of GLII. After demonstrating that $T g f b 1$ is highly expressed in Ptchl-associated RMS of the mouse and ruling out that $T g f b 1$ is a transcriptional target of an activated hedgehog pathway we wanted to see whether overexpression of $T g f b l$ is a more common phenomenon in RMS than in hedgehog-dependent tumors. For this reason we decided to investigate human RMS cell lines for their expression of GLII and TGFB1 by Northern blot analysis. We found a strong GLI1 expression in the three cell lines RH-30, RMS-13, and RH-1, with RMS-13 exhibiting the most prominent expression (Fig. 5). This is in line with the described amplification of GLI1 in RMS-13 cells (35). However, monitoring TGFB1 expression we found high transcript levels throughout all 4 RMS cell lines, with no consistent co-expression of GLII and TGFB1. While the extremely high expression of GLII in RMS-13 cells occurred together with a relatively weak expression of TGFBl on the one hand, RD cells expressed hardly any GLII and very high levels of TGFBI on the other hand. These results clearly demonstrate that the dramatically high expression of $T G F B 1$ is specifically associated with RMS, but independent of hedgehog signaling. 


\section{Discussion}

RMS is an aggressive soft-tissue tumor affecting mainly children and young adults (4). Since the development of new therapies has been hampered by the lack of knowledge about the exact molecular basis of this pediatric tumor, RMS is still associated with a high mortality. Thus, identification of novel genes implicated in the genesis of RMS is of uttermost importance. In view of the fact that human RMS are relatively rare and that RMS of the Ptchl knockout mouse model mirror the histological and molecular features of human RMS (12-14), we have analyzed variations of gene expression in these murine RMS by using the cDNA array technology.

A significant number of the 25 candidates depicted in our study (e.g., Igf2, Vil2, p53, p21, Vim, Itgb1, Myl4) has been already described in earlier studies to be implicated in the formation and progression of RMS. The most prominent candidate gene identified codes for the survival factor IGF2, which has been known for years to be highly expressed in human RMS (36,37). In vitro assays have moreover shown that IGF2 can act as an autocrine growth factor in RMS cells, and also as a promoter of cellular motility (36). Interestingly, RMS of Ptch $1^{\text {neo67/+ }}$ mice mirror the high $I g f 2$ transcript levels found in human RMS and develop only in the presence of functional Igf2, as revealed by a genetic double knockout (Ptch $1^{\text {neo67//+/Igf } 2^{+/} \text {) }}$ approach $(11,12)$. Another appealing gene we detected was Vil2 encoding the membrane-cytoskeletal linking protein ezrin. This gene has been found heavily overexpressed in metastatic tumors of the hepatocyte growth factor-transgenic and Ink4a/Arf-deficient double-mutant mice, which develop highly invasive RMS by the age of four months (38). Moreover, this study demonstrated a strong correlation of VIL2 expression with metastasis in human RMS. Other candidates like the genes coding for the cell-cycle regulators p53 and p21 have previously been described to be strongly expressed in murine and human RMS, however, correlations with tumor subtype and prognosis were not significant $(14,39)$. Additionally, human RMS has been identified to be nearly consistently positive for vimentin and integrin $\beta$ by means of immunohistochemistry $(9,10,40)$. Recent work has reported a high expression of the human MYL4 gene (homologous to the murine Myl4 gene) in alveolar RMS using cDNA microarrays $(41,42)$. In light of these results it is safe to predict that analyzing the transcriptional signature of murine Ptchl-associated RMS is a valuable approach for the rapid identification of important genes involved in the genesis of human RMS.

The most remarkable finding of our study was the identification of an aberrantly high expression of the $T g f b 1$ gene in Ptchl-associated RMS compared to normal SM. Even though strong expression of TGFB 1 has been described earlier in human RMS and the ERMS cell line RD $(43,44)$, we show here that the elevated $T g f b l$ expression originates from a second $T g f b l$ transcript, which is solely expressed in the tumor. It has been reported that the major murine $T g f b 1$ mRNA species appears as a $2.5 \mathrm{~kb}$ band on Northern blots (45). In addition, a smaller mRNA of about $1.9 \mathrm{~kb}$ has been detected in the murine sarcoma virus-transformed 3T3 line 3B11-1C and the monocytic line pU5-1.8 (45) as well as murine male germ cells (46). Several lines of evidence indicate that the shorter transcript of $1.9 \mathrm{~kb}$ is also induced in injured tissues, such as the infarcted heart (47), carbon tetrachlorideexposed liver $(48,49)$, and carcinogen-treated skin $(50)$. Since it has been speculated that the second promoter region in the $T g f b l$ gene might be involved in regulating the synthesis of this shorter transcript (51) and since we found a putative Gli binding site within this region, we reasoned whether the tumor-specific transcript found in RMS could be induced by binding of Gli to the P2 promoter of the Tgfbl gene. To verify this hypothesis, we checked for $T g f b 1$ expression by following three different modes of active hedgehog signaling in three different cell/tissue types: transient Glil transfection in murine NIH-3T3 cells, Shh-N stimulation in murine C2C12 myoblasts, and constitutively active hedgehog signaling in Ptch1-deficient mouse embryos. However, our results entirely argue against a direct induction of a second $T g f b l$ transcript by hedgehog signaling. We rather assume that Tgfbl overexpression is a common phenomenon in RMS independent of hedgehog signaling, since we have detected high TGFB1 RNA levels in four human RMS cell lines independently of their GLII expression status.

This assumption is substantiated by the finding that Tgfb1 has differentiation inhibiting and growth inducing effects on myogenic cells. TGF- $\beta$ family members function as potent inhibitors of terminal muscle differentiation $(52,53)$ by silencing the transcriptional activation of MyoD and myogenin, two members of the bHLH family $(54,55)$. This inhibition of differentiation by TGFB 1 persists even in nonmuscle cell lines engineered to ectopically express members of the bHLH family (54-56). Recent studies have described that overproduction of TGFB1 and an autocrine TGFB1 loop is responsible for the growth of RMS (57) and that TGFB1 exhibits a growth-inducing effect in human airway smooth muscle cells through a mechanism that requires TGFBP3 expression (58). Interestingly, $T g f b 1$ and $I g f b p 3$ were concomitantly overexpressed in Ptch1-asssociated RMS of our study.

Taken together these data propose an important regulatory function of $\mathrm{Tgfb} 1$ on cell growth and differentiation during the development of RMS, which however, is independent of an activated hedgehog signaling pathway.

\section{Acknowledgements}

We are grateful to Ina Hess and Astrid Herwig for excellent animal care and technical assistance and to Danielle Wendling for critically reviewing the manuscript. We thank Hiroshi Sasaki (Osaka University) and Daniela Laubner (GSF Neuherberg) for kindly providing the murine Gli1 cDNA and the p11x-Gli1-BS reporter plasmid, respectively.

\section{References}

1. Crist WM and Kun LE: Common solid tumors of childhood. N Engl J Med 324: 461-471, 1991.

2. Merlino G and Helman LJ: Rhabdomyosarcoma - working out the pathways. Oncogene 18: 5340-5348, 1999.

3. Newton WA, Gehan EA, Webber BL, et al: Classification of rhabdomyosarcomas and related sarcomas. Pathologic aspects and proposal for a new classification - an Intergroup Rhabdomyosarcoma Study. Cancer 76: 1073-1085, 1995. 
4. Crist WM, Anderson JR, Meza JL, Fryer C, Raney RB, Ruymann FB, Breneman J, Qualman SJ, Wiener E, Wharam M, Lobe T, Webber B, Maurer HM and Donaldson SS: Intergroup rhabdomyosarcoma study-IV: results for patients with nonmetastatic disease. J Clin Oncol 19: 3091-3102, 2001.

5. Anderson J, Gordon A, Pritchard-Jones K and Shipley J: Genes, chromosomes, and rhabdomyosarcoma. Genes Chromosomes Cancer 26: 275-285, 1999.

6. Visser M, Sijmons C, Bras J, Arceci RJ, Godfried M, Valentijn LJ, Voute PA and Baas F: Allelotype of pediatric rhabdomyosarcoma. Oncogene 15: 1309-1314, 1997.

7. Shapiro DN, Sublett JE, Li B, Downing JR and Naeve CW: Fusion of PAX3 to a member of the forkhead family of transcription factors in human alveolar rhabdomyosarcoma. Cancer Res 53: 5108-5112, 1993.

8. Davis RJ, D'Cruz CM, Lovell MA, Biegel JA and Barr FG: Fusion of PAX7 to FKHR by the variant t(1;13)(p36;q14) translocation in alveolar rhabdomyosarcoma. Cancer Res 54: 2869-2872, 1994.

9. Wijnaendts LC, van der Linden JC, van Unnik AJ, Delemarre JF, Barbet JP, Butler-Browne GS and Meijer CJ: Expression of developmentally regulated muscle proteins in rhabdomyosarcomas. Am J Pathol 145: 895-901, 1994.

10. Fletcher CD: Immunohistochemistry in diagnosis of soft tissue sarcomas and new techniques in soft tissue tumour pathology. Recent Results Cancer Res 138: 17-24, 1995.

11. Hahn H, Wojnowski L, Zimmer AM, Hall J, Miller G and Zimmer A: Rhabdomyosarcomas and radiation hypersensitivity in a mouse model of Gorlin syndrome. Nat Med 4: 619-622, 1998.

12. Hahn H, Wojnowski L, Specht K, Kappler R, Calzada-Wack J, Potter D, Zimmer A, Muller U, Samson E and QuintanillaMartinez L: Patched target Igf2 is indispensable for the formation of medulloblastoma and rhabdomyosarcoma. J Biol Chem 275: 28341-28344, 2000.

13. Kappler R, Calzada-Wack J, Schnitzbauer U, Koleva M, Herwig A, Piontek G, Graedler F, Adamski J, Heinzmann U, Schlegel J, Hemmerlein B, Quintanilla-Martinez L and Hahn H: Molecular characterisation of Patched-associated rhabdomyosarcoma. J Pathol 200: 348-356, 2003.

14. Kappler R, Bauer R, Calzada-Wack J, Rosemann M, Hemmerlein B and Hahn H: Profiling the molecular difference between Patched- and p53-dependent rhabdomyosarcoma. Oncogene 23: 8785-8795, 2004.

15. Wicking C, Smyth I and Bale A: The hedgehog signalling pathway in tumorigenesis and development. Oncogene 18: 7844-7851, 1999.

16. Booth DR: The hedgehog signalling pathway and its role in basal cell carcinoma. Cancer Metastasis Rev 18: 261-284, 1999.

17. Hahn H, Wicking C, Zaphiropoulous PG, Gailani MR, Shanley S, Chidambaram A, Vorechovsky I, Holmberg E, Unden AB, Gillies S, Negus K, Smyth I, Pressman C, Leffell DJ, Gerrard B, Goldstein AM, Dean M, Toftgard R, Chenevix-Trench G, Wainwright B and Bale AE: Mutations of the human homolog of Drosophila patched in the nevoid basal cell carcinoma syndrome. Cell 85: 841-851, 1996.

18. Johnson RL, Rothman AL, Xie J, Goodrich LV, Bare JW, Bonifas JM, Quinn AG, Myers RM, Cox DR, Epstein EH and Scott MP: Human homolog of patched, a candidate gene for the basal cell nevus syndrome. Science 272: 1668-1671, 1996.

19. Gorlin RJ: Nevoid basal-cell carcinoma syndrome. Medicine 66: 98-113, 1987 .

20. Calzada-Wack J, Schnitzbauer U, Walch A, Wurster KH, Kappler R, Nathrath M and Hahn H: Analysis of the PTCH coding region in human rhabdomyosarcoma. Hum Mutat 20: 233-234, 2002.

21. Tostar U, Malm CJ, Meis-Kindblom JM, Kindblom LG, Toftgard R and Unden AB: Deregulation of the hedgehog signalling pathway: a possible role for the PTCH and SUFU genes in human rhabdomyoma and rhabdomyosarcoma development. J Pathol 208: 17-25, 2006.

22. Schena M, Shalon D, Davis RW and Brown PO: Quantitative monitoring of gene expression patterns with a complementary DNA microarray. Science 270: 467-470, 1995.

23. Golub TR, Slonim DK, Tamayo P, Huard C, Gaasenbeek M, Mesirov JP, Coller H, Loh ML, Downing JR, Caligiuri MA, Bloomfield CD and Lander ES: Molecular classification of cancer: class discovery and class prediction by gene expression monitoring. Science 286: 531-537, 1999.
24. Alizadeh AA, Eisen MB, Davis RE, et al: Distinct types of diffuse large B-cell lymphoma identified by gene expression profiling. Nature 403: 503-511, 2000.

25. Bhattacharjee A, Richards WG, Staunton J, Li C, Monti S, Vasa P, Ladd C, Beheshti J, Bueno R, Gillette M, Loda M, Weber G, Mark EJ, Lander ES, Wong W, Johnson BE, Golub TR, Sugarbaker DJ and Meyerson M: Classification of human lung carcinomas by mRNA expression profiling reveals distinct adenocarcinoma subclasses. Proc Natl Acad Sci USA 98: 13790-13795, 2001.

26. Korkola JE, De Vries S, Fridlyand J, Hwang ES, Estep AL, Chen YY, Chew KL, Dairkee SH, Jensen RM and Waldman FM: Differentiation of lobular versus ductal breast carcinomas by expression microarray analysis. Cancer Res 63: 7167-7175, 2003.

27. Dhanasekaran SM, Barrette TR, Ghosh D, Shah R, Varambally S, Kurachi K, Pienta KJ, Rubin MA and Chinnaiyan AM: Delineation of prognostic biomarkers in prostate cancer. Nature 412: 822-826, 2001.

28. Sambrook J, Fritsch EF and Maniatis T: Molecular Cloning: a Laboratory Manual. Cold Spring Harbor, Cold Spring Harbor Laboratory Press, 1989.

29. Geiser AG, Kim SJ, Roberts AB and Sporn MB: Characterization of the mouse transforming growth factor-beta 1 promoter and activation by the Ha-ras oncogene. Mol Cell Biol 11: 84-92, 1991.

30. Gustin K and Burk RD: PCR-directed linker scanning mutagenesis. In: Methods in Molecular Biology. Tymms MJ (ed.) Humana Press Inc., Totowa, pp85-90, 2000.

31. Beer C, Buhr P, Hahn H, Laubner D and Wirth M: Gene expression analysis of murine cells producing amphotropic mouse leukaemia virus at a cultivation temperature of 32 and 37 degrees C. J Gen Virol 84: 1677-1686, 2003.

32. Sasaki H, Hui C, Nakafuku M and Kondoh H: A binding site for Gli proteins is essential for HNF-3beta floor plate enhancer activity in transgenics and can respond to Shh in vitro. Development 124: 1313-1322, 1997.

33. Kinzler KW, Ruppert JM, Bigner SH and Vogelstein B: The GLI gene is a member of the Kruppel family of zinc finger proteins. Nature 332: 371-374, 1988

34. Chen JK, Taipale J, Cooper MK and Beachy PA: Inhibition of Hedgehog signaling by direct binding of cyclopamine to Smoothened. Genes Dev 16: 2743-2748, 2002.

35. Khatib ZA, Matsushime H, Valentine M, Shapiro DN, Sherr CJ and Look AT: Coamplification of the CDK4 gene with MDM2 and GLI in human sarcomas. Cancer Res 53: 5535-5541, 1993.

36. El-Badry OM, Minniti C, Kohn EC, Houghton PJ, Daughaday WH and Helman LJ: Insulin-like growth factor II acts as an autocrine growth and motility factor in human rhabdomyosarcoma tumors. Cell Growth Differ 1: 325-331, 1990.

37. Zhan S, Shapiro DN and Helman LJ: Activation of an imprinted allele of the insulin-like growth factor II gene implicated in rhabdomyosarcoma. J Clin Invest 94: 445-448, 1994.

38. Yu Y, Khan J, Khanna C, Helman L, Meltzer PS and Merlino G: Expression profiling identifies the cytoskeletal organizer ezrin and the developmental homeoprotein Six-1 as key metastatic regulators. Nat Med 10: 175-181, 2004.

39. Takahashi Y, Oda Y, Kawaguchi K, Tamiya S, Yamamoto H, Suita S and Tsuneyoshi M: Altered expression and molecular abnormalities of cell-cycle-regulatory proteins in rhabdomyosarcoma. Mod Pathol 17: 660-669, 2004.

40. Mechtersheimer G, Barth T, Quentmeier A and Moller P: Differential expression of beta 1 integrins in non-neoplastic smooth and striated muscle cells and in tumors derived from these cells. Am J Pathol 144: 1172-1182, 1994.

41. Khan J, Bittner ML, Saal LH, Teichmann U, Azorsa DO, Gooden GC, Pavan WJ, Trent JM and Meltzer PS: cDNA microarrays detect activation of a myogenic transcription program by the PAX3-FKHR fusion oncogene. Proc Natl Acad Sci USA 96: 13264-13269, 1999.

42. Khan J, Simon R, Bittner M, Chen Y, Leighton SB, Pohida T, Smith PD, Jiang Y, Gooden GC, Trent JM and Meltzer PS: Gene expression profiling of alveolar rhabdomyosarcoma with cDNA microarrays. Cancer Res 58: 5009-5013, 1998.

43. Derynck R, Goeddel DV, Ullrich A, Gutterman JU, Williams RD, Bringman TS and Berger WH: Synthesis of messenger RNAs for transforming growth factors alpha and beta and the epidermal growth factor receptor by human tumors. Cancer Res 47: 707-712, 1987. 
44. McCune BK, Patterson K, Chandra RS, Kapur S, Sporn MB and Tsokos M: Expression of transforming growth factor-beta isoforms in small round cell tumors of childhood. An immunohistochemical study. Am J Pathol 142: 49-58, 1993.

45. Derynck R, Jarrett JA, Chen EY and Goeddel DV: The murine transforming growth factor-beta precursor. J Biol Chem 261: 4377-4379, 1986.

46. Watrin F, Scotto L, Assoian RK and Wolgemuth DJ: Cell lineage specificity of expression of the murine transforming growth factor beta 3 and transforming growth factor beta 1 genes. Cell Growth Differ 2: 77-83, 1991.

47. Qian SW, Kondaiah P, Casscells W, Roberts AB and Sporn MB: A second messenger RNA species of transforming growth factor beta 1 in infarcted rat heart. Cell Regul 2: 241-249, 1991.

48. Czaja MJ, Flanders KC, Biempica L, Klein C, Zern MA and Weiner FR: Expression of tumor necrosis factor-alpha and transforming growth factor-beta 1 in acute liver injury. Growth Factors 1: 219-226, 1989.

49. Czaja MJ, Weiner FR, Flanders KC, Giambrone MA, Wind R, Biempica L and Zern MA: In vitro and in vivo association of transforming growth factor-beta 1 with hepatic fibrosis. J Cell Biol 108: 2477-2482, 1989.

50. Sherman JH, Baxter CS and Albert RE: Stimulation of TGFbeta 1 mRNA concentration in mouse skin treated with benzo [a]pyrene. Carcinogenesis 13: 83-86, 1992.

51. Romeo D, Allison RS, Kondaiah P and Wakefield LM: Recharacterization of the start sites for the major human transforming growth factor-beta 1 mRNA. Gene 189: 289-295, 1997.
52. Allen RE and Boxhorn LK: Inhibition of skeletal muscle satellite cell differentiation by transforming growth factor-beta. J Cell Physiol 133: 567-572, 1987.

53. Katagiri T, Akiyama S, Namiki M, Komaki M, Yamaguchi A, Rosen V, Wozney JM, Fujisawa-Sehara A and Suda T: Bone morphogenetic protein-2 inhibits terminal differentiation of myogenic cells by suppressing the transcriptional activity of MyoD and myogenin. Exp Cell Res 230: 342-351, 1997.

54. Martin JF, Li L and Olson EN: Repression of myogenin function by TGF-beta 1 is targeted at the basic helix-loop-helix motif and is independent of E2A products. J Biol Chem 267: 10956-10960, 1992

55. Brennan TJ, Edmondson DG, Li L and Olson EN: Transforming growth factor beta represses the actions of myogenin through a mechanism independent of DNA binding. Proc Natl Acad Sci USA 88: 3822-3826, 1991.

56. Vaidya TB, Rhodes SJ, Taparowsky EJ and Konieczny SF: Fibroblast growth factor and transforming growth factor beta repress transcription of the myogenic regulatory gene MyoD1. Mol Cell Biol 9: 3576-3579, 1989.

57. Bouche M, Canipari R, Melchionna R, Willems D, Senni MI and Molinaro M: TGF-beta autocrine loop regulates cell growth and myogenic differentiation in human rhabdomyosarcoma cells. FASEB J 14: 1147-1158, 2000.

58. Cohen P, Rajah R, Rosenbloom J and Herrick DJ: IGFBP-3 mediates TGF-betal-induced cell growth in human airway smooth muscle cells. Am J Physiol 278: L545-L551, 2000. 